\title{
Analysis and Reuse of the Fine Waste of a Residual Solid Treatment Plant of a Concrete Company to Prepare a Mortar with Hydraulic Cement
}

\author{
Hernandez-García J. R. ${ }^{1, *}$, Aranda-Jiménez Y. ${ }^{1}$, Sánchez-Medrano Ma. T. ${ }^{1}$, Lozano-Navarro J. ${ }^{2}$ \\ ${ }^{1}$ Faculty of Architecture, Design and Urbanism, University Autonomous of Tamaulipas, Circuito Universitario S/N, Centro \\ Universitario Sur, Tampico, Tamaulipas, Mexico \\ ${ }^{2}$ Institute of Engineering, National Autonomous University of Mexico, Ciudad Universitaria, Mexico City, Mexico
}

Received June 19, 2021; Revised August 9, 2021; Accepted September 21, 2021

\section{Cite This Paper in the following Citation Styles}

(a): [1] Hernandez-García J. R., Aranda-Jiménez Y., Sánchez-Medrano Ma. T., Lozano-Navarro J., "Analysis and Reuse of the Fine Waste of a Residual Solid Treatment Plant of a Concrete Company to Prepare a Mortar with Hydraulic Cement," Civil Engineering and Architecture, Vol. 9, No. 6, pp. 1938-1954, 2021. DOI: 10.13189/cea.2021.090624.

(b): Hernandez-García J. R., Aranda-Jiménez Y., Sánchez-Medrano Ma. T., Lozano-Navarro J. (2021). Analysis and Reuse of the Fine Waste of a Residual Solid Treatment Plant of a Concrete Company to Prepare a Mortar with Hydraulic Cement. Civil Engineering and Architecture, 9(6), 1938-1954. DOI: 10.13189/cea.2021.090624.

Copyright $\bigcirc 2021$ by authors, all rights reserved. Authors agree that this article remains permanently open access under the terms of the Creative Commons Attribution License 4.0 International License

\begin{abstract}
The purpose of the investigation is the use of a residual material through its recovery in a concrete mixer located in the town of Ixtaczoquitlan, Ver., Mexico, to make a recycled hydraulic mortar of $\mathrm{f}^{\prime} \mathrm{c} 70 \mathrm{~kg} / \mathrm{cm}^{2}$ for masonry works, providing sustainability to the concrete mixer and to determine its compressive strength compared to a normal mortar. The methodology consists of the recovery of a sample of fine waste of concrete from the treatment plant in CAGSA (Constructoras Asociadas del Golfo S. A. de C. V.), to dry it, classify it and then make mixtures with $\%$ fine waste- $\%$ mine sand (in a percentage ratio of $10 \%-90 \%, 20 \%-80 \%, 30 \%-70 \%, 40 \%-60 \%, 50 \%$ $-50 \%$ and $60 \%-40 \%$ ), as well as, water and cement, to later compare the results against a sample control and evaluate its compressive strengths. The results of compatibility with the other materials that make up the mortar are favorable and benefit its homogeneity and fluidity. The best compression strengths are mixtures at $10 \%-90 \%$, and $20 \%$ $-90 \%$. In conclusion, this residue is compatible with the materials that make up the mortar and can be used to glue partitions and masonry plaster. Within the new and relevant aspects of the study is confirmation of the use of a new mortar from fine concrete waste, mixed with andesite-type mine sand, strengthening the sustainability of the environment. It was investigated that the analyzed residues contain $90 \%$ of Calcium, which is used in the
\end{abstract}

manufacture of accelerating additives for concrete, based on calcium chloride. It can be a raw material to make additives that accelerate resistance. Follow-up research is recommended regarding the slump test, fluidity, compressive strength, consistency, and water retention of this type of mortar with fine recycled aggregate.

Keywords Concrete, Mixtures, Mortar, Recycled, Samples, Sustainability, Waste, Recycled Aggregate

\section{Introduction}

As part of a sustainability strategy taken at the global level, the actions of recycling and reusing any material are of relevant importance in order to guarantee the inheritance of a livable world to our descendants. Since that human activity generates the highest pollution and generation of garbage and waste [1], projects are required to mitigate the impact of these wastes, particularly those generated in construction.

The need for recycling and reuse must be a systematized activity in every country. As mentioned, Erik and Niels [2], waste should be limited in accordance with the demands of environmental protection and the lack of appropriate 
deposit, in addition to using the waste for proper recycling and reuse, mitigating energy costs; this leads to cleaner technologies that correspond to sustainability requirements. In this regard, Elizabeth [3] opportunely points out that this increase in waste occurs due to the increase in population, which, when demanding new construction, originates a large amount of solid waste, including construction waste (RC) then the construction industry is an area of opportunity because it generates a significant amount of waste that can be recycled and reused in new works.

In the construction industry, waste is produced throughout the life cycle of materials, from extraction to the end of life, a large part of this waste is represented by so-called concrete and demolition waste (RCD), which includes concrete, steel, glass, masonry, asphalt, and other materials found on construction or demolition sites; also, in construction sites of civil engineering works such as roads and bridges. Particularly concrete RCD comprises concrete in all its forms, found in construction and demolition waste. Including concrete elements, parts, pieces and blocks recovered during construction and demolition activities. It can be extracted directly from the sites or from the construction and demolition materials once they have been separated.

With regard to the recovery of construction and demolition waste, it is important to know how these materials are classified in order to know their possible use and destination in their new reuse and/or recycling process, regarding this Alfonso [4], classifies them as reusable, recyclable materials and intended for the manufacture of secondary products.

To measure environmental performance in the treatment and management of waste, the methodology for the analysis and life cycle has been used [5].

Up to this point of the research, only urban solid waste, where concrete and demolition waste is included, has been discussed as a reference and antecedent, the focus of the work is based on the recovery of fine solid waste from a treatment plant from a concrete mixer.

The foregoing with the purpose of developing a masonry mortar made with waste products from a concrete plant that favors the concepts of sustainability without compromising quality and resistance in construction.

Regarding research work made about mortars using fine waste in its manufacture, the author Enrique [6], in his doctoral thesis named "Application of waste in the manufacture of industrial mortars", intends to do a related study with the use of the fine fraction of construction waste and demolition (RCD) in the manufacture of masonry mortars. He used two types of recycled aggregates, one from concrete waste (FRCA) and another of mixed waste of blocks with a high percentage of ceramic red brick. Its goal is to design and manufacture industrial masonry mortars from the fine fraction of recycled aggregates of construction and demolition waste (RCD), contributing to the development of a sustainable construction and giving added value to this type of materials. Its method consists of observation of the behavior of its characteristics in a fresh and dry state, he determined the consistency of the fresh mortar fulfilling the value of $175 \pm 10 \mathrm{~mm}$ will be verified on all mixtures according to the procedure described in the UNE-EN 1015-3-1999 [7] standard. In the masonry mortars manufactured with recycled fine aggregates, he observed three properties of fresh mortar which were characterized by its density, air content and workability. In the hardened mortar was characterized according to six properties: dry apparent density, compression and flexion resistance, the dimensional instability (contraction), adhesive force, the water absorption due to capillary action and water steam permeability. Four different mixtures of each type of mortar were made. After analyzing in detail, the results obtained, raises as the most relevant conclusions, in relation to the physical-mechanical properties, that the recycled sands of RCD tested has a continuous granulometry, more fines, lower density, increased water absorption, reduced resistance to fragmentation (friability), greater loss on calcination and less sand equivalent than natural silica sand used as a reference. In relation to chemical properties, the recycled sands of RCD tested are composed mainly of quartz, they have a greater amount of total sulfur compounds, soluble salts and water and acid soluble sulfates than natural sand. The RCD recycled sands tested are composed mainly of quartz,

Similarly it is the one made by the researcher Carmelo [8] with his research: "Physical properties and durability of mortars lightened with expanded clay and aggregates with recycled aggregates", where he also adds another element such as expanded clay for his experimentation and comments that the massive use of natural resources by humanity for its benefit, has been a constant through the time, unconsciously collaborating in the degradation of the environment and in the progressive deterioration of the environment. The generation of Construction and Demolition Waste (RCDs) is closely linked to constructive activity, a significant part of this waste is deposited in landfills, causing a visual impact and landscaped, in addition to a negative ecological impact when rejecting materials that with adequate treatment, could be recycled. This problem has been worsening since 2008 with the financial crisis, since more than $50 \%$ of the rubbles produced even some potentially dangerous, end up in illegal landfills. Therefore, proper waste management is needed to achieve as much reduction as possible the quantities generated and take advantage of the potential they have as a resource. One of the most widespread uses of RCDs is its use for the production of recycled aggregates in replacement of natural aggregate.

Similarly, claims that the study of the use of recycled aggregates has been oriented towards the use of coarse aggregates, finding applications in the manufacture of structural concretes and removing fine aggregates. The objective of this work is to find an application for this fine 
fraction, manufacturing light mortars with different types of recycled aggregates. The research that is collected in this thesis is the development of an experimental process for the design of lightweight mortars manufactured with fine recycled aggregates from concrete and mixed rubbles. The different materials used in the mixtures were previously characterized in order to know the starting references, so much for the study of mechanical properties of the mortars designed as from its behavior to durability against external aggressive agents to subsequently replace the natural aggregate of the reference mortar by recycled concrete aggregate (ARH) and mixed (ARM) originating the design mortars.

In another perspective about the subject, Eduardo and Francisco [9], they say that the search for new options to take advantage of fine waste from the crushing of disused concrete or fine dust recycled mortar (FMR) has developed processes based on heat treatment that allows incorporating this material to the manufacture of new concrete. Applying these thermal processes, the author's research determines the chemical composition of the fine dust from different samples of calcined recycled mortar (FMRC), collected from various sources, and studies experimentally how in combination with new cement, influences the compressive strength of the composite material. Using a rate of $30 \%$ of FMRC as a replacement for ordinary Portland cement (CPO) for the manufacture of specimens, the study determines that the direct use of this material, negatively affects to compressive strength of the composite material, reaching in most specimens from $21 \%$ to $54 \%$ of the resistance to normal compression. Based on the theoretical study of the ratio $\mathrm{Ca} / \mathrm{Si}(\mathrm{T}-\mathrm{Ca} / \mathrm{Si})$, it is observed how the compressive strength is related to the $\mathrm{Ca} / \mathrm{Si}$ balance of the mixture, where the test pieces with higher $\mathrm{Ca} / \mathrm{Si}$ rate reach a compressive strength of $72 \%$, compared to the mixtures using only cement. Finally, the experimental study indicates that the main criterion for evaluating the recycling of FMR is the calcium oxide concentration $(\mathrm{CaO})$, there are no significant differences between concrete waste and mortar prepared and put into work, unlike special or pre-mixed mortar waste.

About the same RCD, Gilberto and Monica [10] investigate the influence of the relationship of the recycled fine aggregate of mortar, replacing the natural fine aggregates by fine aggregate of RCD and in turn analyze the influence on the mixing sequence on their yields, for which they use two percentages of RCD for the elaboration of the experiments according to Brazilian standards both percentages are $20 \%$ and $40 \%$, the ratio of the mixture is 1:5 (cement and aggregate by weight). In this regard they conclude that partial replacement improves some properties of mortars with RCD as air content and the rate of water absorption by capillarity decreases, while mechanical performance increases.

A very interesting work on the addition of waste to replace the fine aggregate is the one presented by Alexis and Aldo [11] which is a study of a "Hydraulic mortar where the wood shaving was used in place of the fine arid by partial percentages", where it was sought to evaluate the mechanical behavior of the prototype of concrete designed, the above in order to re-use the waste of the chip and avoid contamination with its waste. Another of their objectives is to find the correct dosage to meet the parameter designs established by the MTOP (Ministry of Transport and Public Works) in the mortars, the type of research they used for this project was an analytical type of research, which allowed them to analyze the data in an experimental way in the prototype of mortar designed. As for the results obtained, it was concluded that the best percentage of mixture was $0.5 \%$, in place of the fine aggregate, the best performance to compression since the designs while the percentage of wood shaving was increased under the compressive strength of the mortar, because the water / cement ratio was also affected by the chip so that the arid in question absorbed the greatest amount of water in the preparation of kneading.

With regard to the determination of the resistance to compression in mortars with recycled fine aggregates product of the RCD [12], carries out a series of investigations that allow it to forecast this test by means of a mechanical simulation of the material using the ANSYS software, using the finite element method, commenting that given the cost and time involved in such tests, the need arises to handle new tools such as simulation in order to obtain answers and results in a way prior to the physical designs of any type of mixture and material so that it can be identified what the behavior of the element will be before different loads and affectations without the need for the existence of the material and without performing physical tests, allowing to obtain results where factors such as time and costs are generously reduced.

On the improvement of compressive strengths in mortars with AFR (Recycled Fine Aggregates) and AGR (Recycled Coarse Aggregates), [13] based on other research regarding the mechanical behavior of mortars made with AFR and AGR, $[14,15,16,6]$ agree that mechanical resistances vary in relation to the absorption of water in the AFR and AGR, this related to the density of the same affecting the relationship a/c (water/cement), in this regard they propose as a solution, the improvement of these mechanical behaviors and especially that of the resistance to compression, through the use of the methodology of accelerated carbonation with carbon dioxide $\left(\mathrm{CO}_{2}\right)$, for the study, carried out by the authors, a mortar with natural fine aggregate was elaborated as a specimen, and samples of study with AFR as a fine aggregate. The origin of the AFR was from the grinding of laboratory cylinders, the mortar was designed for a compressive strength of $17.5 \mathrm{MPa}$, the ratios of the mixtures were as follows: $0 \%$ replacement represents the control mixture, while the values of $25 \%$ and $50 \%$ represent the replacement of AFN (Natural Fine Aggregate), by AFR and AFRC (Carbonated Recycled 
Fine Aggregate).

The conclusions they reached are that in general, the mixtures with AFR showed a pronounced detriment of the resistance to compression, however, the mixtures that had AFRC incorporated showed a similar or slightly lower behavior than the standard mixtures, from the above results it is inferred that the porosity of the mortar with addition of AFR is not fully compensated by its filling effect, in addition, the lower density and higher absorption of AFR has a negative impact on its resistance.

With regard to Julián et al. [17] in his research called "Study of the behavior of natural mortar samples subjected to compression stresses" he focuses as specified in his study, on the behavior of the resistance of a traditional natural mortar, compared with a Portland hydraulic mortar. According to his research, these natural mortars were manufactured with non-hydraulic lime and their hydraulicity is due to the addition of ceramics, in this research the author uses pozzolan and quicklime as a stone and cementing material respectively as a substitute compared to Portland mortar. With regard to the replacement of the stone material, this was replaced by artificial aggregate called pozzolan, recovered from the waste of ceramic material from constructions the design resistance of the control mortar is $17.2 \mathrm{MPa}$ for this research the following variables were determined: Gypsum, pozzolan, lime, and water, with minimum and maximum levels between $(0-35 \mathrm{~g}), \quad(480-550 \mathrm{~g}), \quad(80-100 \mathrm{~g})$ and 160-190g) respectively. To produce an $\mathrm{m}^{3}$ of mortar were used $23.81 \%$ water, $11.66 \%$ quicklime $60.15 \%$ pozzolan, and $4.39 \%$ gypsum. The conclusions of this research are as follows according to the results: for a natural mortar, it can be said that, as a structural material for transmission of loads are obtained very low resistances, it is observed that the yeso affects in an important way the resistance of these mortars, since they presented failures in the material prior to their compression test, in this situation, internal tractions are generated that the mortar cannot resist.

\section{Summary of Works Related to this Research}

Author: Gilberto and Monica [10], Material investigated: Recycled fine aggregate, Type of mortar: Hydraulic mortar cement-sand, Specimen resistance at 28 days: $13.5 \mathrm{MPa}$ according to Brazilian standard NBR7215 and $14.3 \mathrm{MPa}$ according to the MDE method, best result to compression at 28 days: $14.3 \mathrm{MPa}$, Percentage of mixtures: $0 \%$, $(20 \%-80 \%)$ and $(40 \%-60 \%)$, Conclusion: The partial replacement of the NFA with the MFRA using the MDE sequence gave the best results. Author: Álvaro et al. [13], Material investigated: Recycled non-carbonated and carbonated fine aggregates, Type of mortar: Hydraulic mortar cement-sand, Specimen resistance at 28 days: 17.5 $\mathrm{MPa}$, Best result to compression at 28 days: $22.0 \mathrm{MPa}$, Percentage of mixtures: $0 \%,(25 \%-50 \%)$ and $(50 \%-50 \%)$,
Conclusion: Non-carbonated AFR does not reach the design resistance, contrary to the case with carbonates that increase it. Author: Julian et al. [17], Material investigated: Ceramic pozzolana and gypsum, Type of mortar: Hydraulic Lime Mortar, Specimen resistance at 28 days: 17.2 MPa, Best result to compression at 28 days: $1.8 \mathrm{MPa}$, Percentage of mixtures: $23.81 \%$ water, $11.6 \%$ quicklime, $60.15 \%$ pozzolan and $14.39 \%$ gypsum, Conclusion: Sedimentation produced by the difference in particle size and the phenomenon of exudation was present in all samples. Author: Alexis and Aldo [11], Material investigated: Wood shaving, Type of mortar: Hydraulic mortar Cement-Sand, Specimen resistance at 28 days: 12.7 $\mathrm{MPa}$, Best result to compression at 28 days: $7.88 \mathrm{MPa}$, Percentage of mixtures: $0 \%, \quad 0.05 \%-99.95 \%$, 0.80\%-99.20\%, $1.5 \%-98.5 \%$ and $2.5 \%-97.5 \%$, Conclusion: Wood shavings should not be used in the production of mortars as a substitute for fine aggregate since the results obtained through laboratory tests were unfavorable. Nomenclature: $\mathrm{AGR}=$ Recycled coarse aggregate, $\mathrm{AFR}=$ Recycled fine aggregate, $\mathrm{AFRC}=$ Carbonated recycled fine aggregate, $\mathrm{NFA}=$ Natural fine aggregate, MFRA= Recycled fine aggregate of mortar, NBR 7215= Brazilian standard 7215, MDE $=$ Mixing in two stages

\section{Materials and Methods}

\subsection{Materials}

The materials to be used for the preparation of the control mortar, as well as the mortars under investigation will be the following:

1. Andesitic type mine sand from the "Los Sánchez" bank located at a known address in the municipality of Mariano Escobedo, Ver.

As seen in figure 1, for the purpose of making the control mixture, the material was passed in greña by the corresponding sieves until to get the accepted granulometry by the corresponding NMX of the sand, for the elaboration of hydraulic mortars with cement.

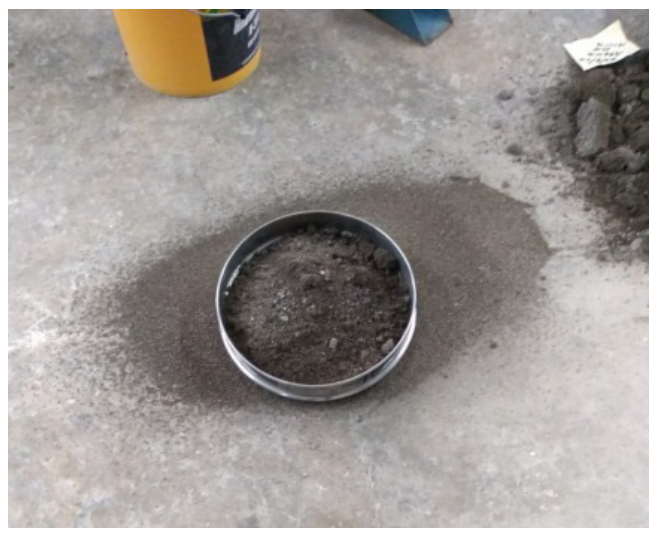

Figure 1. Granulometric classification of the mine sand. Photograph taken by the researcher. 
The data of the sand and results of the physical characteristics obtained from the sand used in research can be seen below in Tables 1 and 2.

Table 1. Test data

\begin{tabular}{|l|l|l|l|}
\hline Place: & CAGSA concrete plant & Origin: & Constructora México - Tamiahua \\
\hline Location: & Ixtaczoquitlan, Ver. & Constructor: & Concrete CAGSA \\
\hline Number of samples: & 1 & Sampling place: & bank of materials of the Sánchez \\
\hline Description: & $\begin{array}{l}\text { Sand of andesite origin } \\
\text { Sand with screening process }\end{array}$ & Sampling date: & $04 / 22 / 2020$ \\
\hline & & Amount of material received: & $200.0 \mathrm{~kg}$ \\
\hline
\end{tabular}

Table 2. Physical characteristics of mine sand

\begin{tabular}{|l|c|c|}
\hline Physical tests & Sand & Specified limits \\
\hline Density $(\mathrm{s} \mathrm{s} \mathrm{s})\left(\mathrm{kg} / \mathrm{m}^{3}\right)$ & 2590 & Minimum 2.45 \\
\hline Absorption $(\%)$ & 4.55 & \\
\hline Loose volumetric weight $\left(\mathrm{kg} / \mathrm{m}^{3}\right)$ & 1390 & \\
\hline Compact volumetric weight $\left(\mathrm{kg} / \mathrm{m}^{3}\right)$ & 1630 & \% Maximum 5 \\
\hline Loss by washing $(\%)$ & 7.90 & \% Maximum 80 \\
\hline Sand equivalent $(\%)$ & 95.00 & Range 2.0 \\
\hline Organic matter colorimetry (range) & 1.00 & \\
\hline
\end{tabular}

In relation to the granulometric composition of the sand used in the elaboration of the control mortar, this is represented in the following table. (See Table 3)

Table 3. Granulometric composition of mine sand

\begin{tabular}{|c|c|c|c|}
\hline \multirow{2}{*}{ Sieve number } & \multicolumn{2}{|c|}{ Accumulated limits } & \multirow{2}{*}{ Material Retained accumulate } \\
\cline { 2 - 4 } & Min. & 5 & 4.30 \\
\hline 4 & 0 & 20 & 22.00 \\
\hline 8 & 0 & 50 & 40.10 \\
\hline 16 & 15 & 75 & 57.00 \\
\hline 30 & 40 & 90 & 67.20 \\
\hline 50 & 70 & 98 & 86.00 \\
\hline 100 & 90 & & 92.10 \\
\hline 200 & & 100 & 100.00 \\
\hline Pan & 100 & 3.1 & 2.77 \\
\hline Fine module & 2.3 & \\
\hline
\end{tabular}

As for the granulometric curve of the same, this can be seen in the following graph. (See Graph 1) 

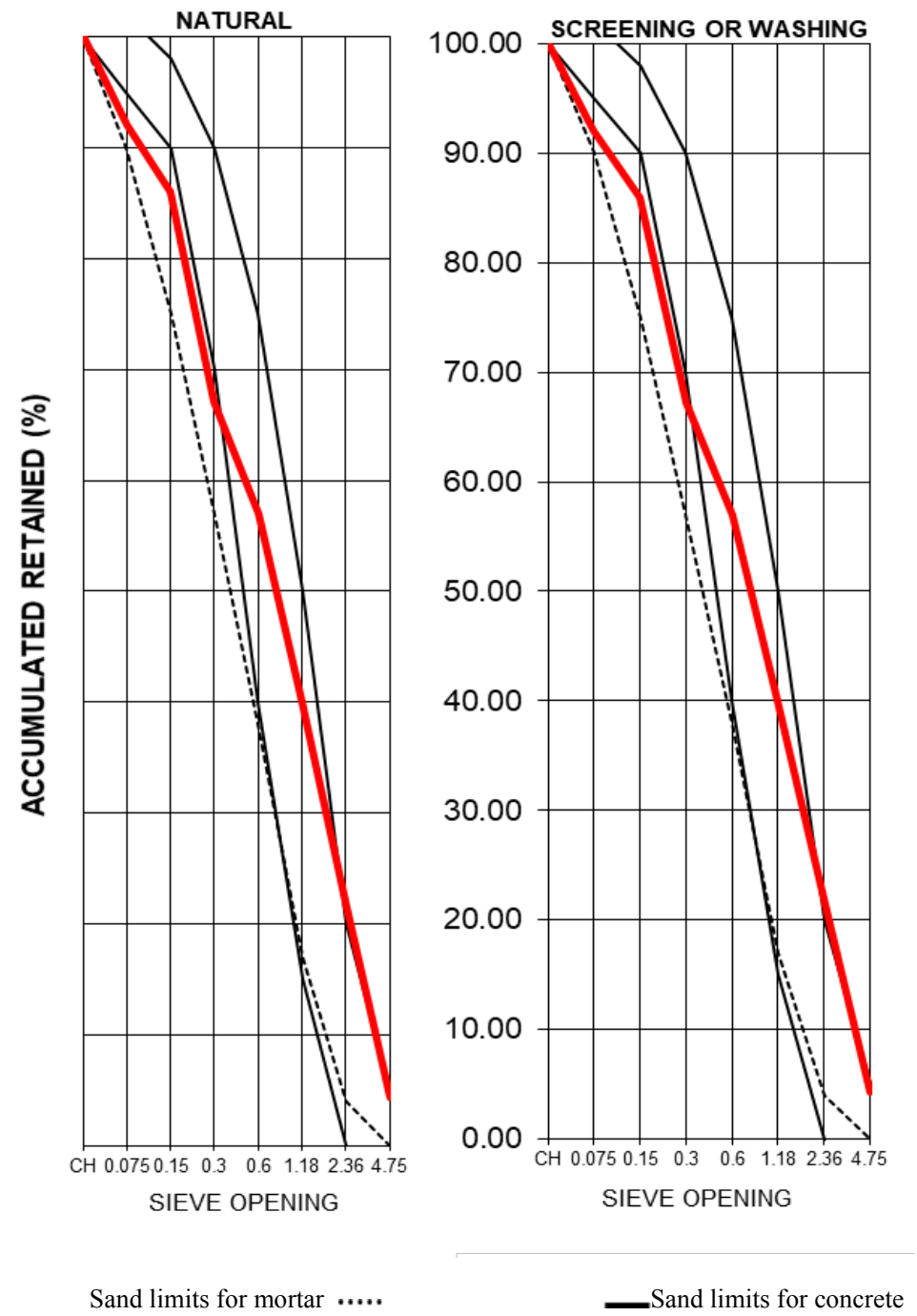

Sand limits for mortar $\ldots . .$.

Graph 1. Granulometric curve of mine sand

2. Fine waste of concrete. This material is from the treatment plant of the company Concrete CAGSA.

The waste material used in the research is dried in order to work it, since this, being always inside the treatment plant, is saturated with water. In Figure 2 can be appreciated the material already dry and screened, which is characterized by a light grayish color.

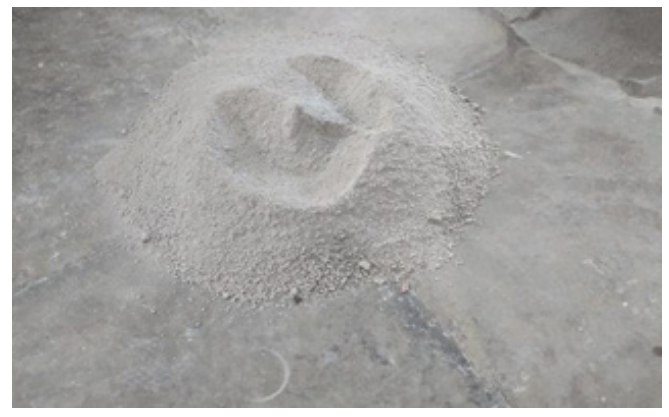

Figure 2. Granulometric classification of material recovered from the treatment plant 
Regarding the data and characteristics of the physical analysis carried out on this material, they can be seen below in Table 4 and 5.

Table 4. Test data

\begin{tabular}{|c|c|c|c|}
\hline Place: & CAGSA concrete plant & Origin: & Plant of concrete Ixtaczoquitlán \\
\hline Location: & Ixtaczoquitlán, Ver. & Constructor: & Concrete CAGSA \\
\hline Number of samples: & 2 & Sampling place: & CAGSA concrete plant \\
\hline Description: & $\begin{array}{c}\text { Recycled material from cell 1 } \\
\text { and 2 }\end{array}$ & Sampling date: & $04 / 22 / 2020$ \\
\hline & & Amount of material received: & $100.0 \mathrm{~kg}$ \\
\hline
\end{tabular}

Table 5. Physical characteristics of the recovered fine waste

\begin{tabular}{|c|c|c|}
\hline Physical tests & Sand & Specified limits \\
\hline Density $(\mathrm{s} \mathrm{s} \mathrm{s})\left(\mathrm{kg} / \mathrm{m}^{3}\right)$ & 1010 & Minimum 2.45 \\
\hline Absorption $(\%)$ & 6.50 & \\
\hline Loose Volumetric weight $\left(\mathrm{kg} / \mathrm{m}^{3}\right)$ & 580 & \% Maximum 5 \\
\hline Compact volumetric weight $\left(\mathrm{kg} / \mathrm{m}^{3}\right)$ & 760 & \% Maximum 80 \\
\hline Loss by washing (\%) & 0.00 & Range 2.0 \\
\hline Sand equivalent $(\%)$ & 0.00 & \\
\hline Organic matter colorimetry (range) & 0.00 & \\
\hline
\end{tabular}

Regarding the granulometric composition of fine waste of the concrete is according to Table 6 .

Table 6. Granulometric composition of the fine waste

\begin{tabular}{|c|c|c|c|}
\hline \multirow{2}{*}{ Sieve number } & \multicolumn{2}{|c|}{ Accumulated limits } & \multirow{2}{*}{$\begin{array}{l}\text { Material Retained } \\
\text { accumulated }\end{array}$} \\
\hline & Min. & Max. & \\
\hline 4 & 0 & 5 & 0.00 \\
\hline 8 & 0 & 20 & 0.00 \\
\hline 16 & 15 & 50 & 0.00 \\
\hline 30 & 40 & 75 & 0.00 \\
\hline 50 & 70 & 90 & 0.00 \\
\hline 100 & 90 & 98 & 0.00 \\
\hline 200 & & & 0.00 \\
\hline Pan & 100 & 100 & 0.00 \\
\hline Fine module & 2.3 & 3.1 & 0.00 \\
\hline
\end{tabular}

The granulometric curve of the fine waste of the concrete according to the laboratory analysis is presented in Graphic 2 . 


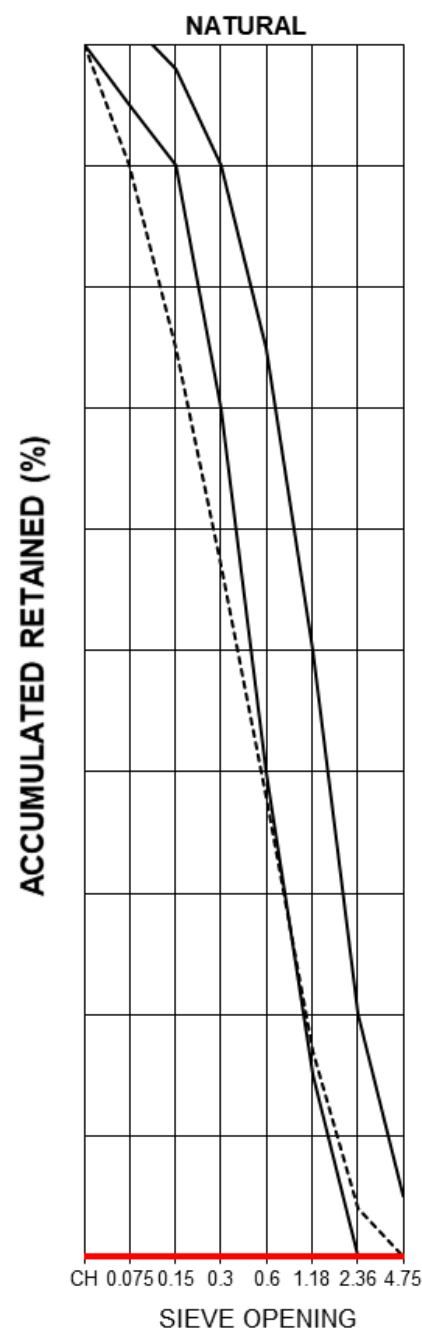

Sand limits for mortar $\ldots . .$.

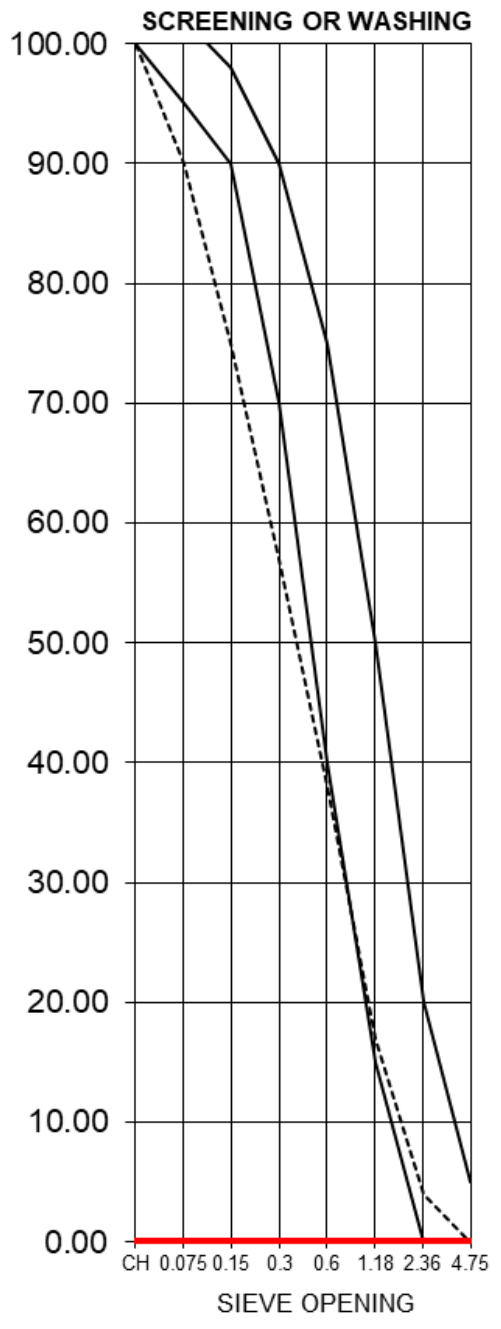

Sand limits for concrete

Graph 2. Granulometric curve of the fine waste material of the treatment plant

Regarding the chemical components found in the recovered material, the following elements were found as shown in Table 7.

Table 7. Chemical content of the material recovered from the PTR of company CAGSA Concrete

\begin{tabular}{|c|c|c|c|c|}
\hline Determination & $\mathbf{\%}$ & Result $\mathbf{( m g} / \mathbf{k g})$ & Result $\mathbf{( g / k g )}$ & Reference \\
\hline Aluminum & 0.015 & 19.100 & 0.0191 & NOM-117-SSA1-1994 \\
\hline Calcium & 90.963 & $112,830.000$ & 112.830 & NOM-117-SSA1-1994 \\
\hline Iron & 5.353 & $6,640.000$ & 6.640 & NOM-117-SSA1-1994 \\
\hline Magnesium & 2.504 & $3,105.900$ & 3.105 & NOM-117-SSA1-1994 \\
\hline Sodium & 0.481 & 596.490 & 0.596 & NOM-117-SSA1-1994 \\
\hline Potassium & 0.683 & 847.340 & 0.847 & NOM-117-SSA1-1994 \\
\hline & 100 & $124,038.830$ & 124.038 & \\
\hline
\end{tabular}

3. Portland cement CPC 40 RS. Regarding this material, is used if the concrete plant considers to be complied the quality requirements according to the corresponding standard, see Table 8. 
Table 8. Cruz Azul cement technical data sheet dated March-2020

\begin{tabular}{|c|c|c|c|c|}
\hline & & $\begin{array}{c}\text { Specification } \\
\text { NMX-C-414-ONNCCE } \\
\end{array}$ & $\begin{array}{c}\text { Result } \\
\text { (MARCH 2020) }\end{array}$ & $\begin{array}{c}\text { Result } \\
\text { (APRIL 2020) } \\
\end{array}$ \\
\hline Chemical analysis & $\mathrm{SO}_{3}(\%)$ & 4.0 máx. & 3.85 & 3.85 \\
\hline \multirow[b]{2}{*}{ Physical tests } & Blaine $\left(\mathrm{cm}^{2} / \mathrm{g}\right)$ & - & 4570 & 4570 \\
\hline & $\begin{array}{c}\% \text { Retained Sieve } 325 \\
(45 \mu \mathrm{m})\end{array}$ & - & 1.8 & 1.5 \\
\hline \multirow{2}{*}{ Health (\%) } & Expansion & 0.80 max. & 0.009 & 0.011 \\
\hline & Contraction & 0.20 max. & --- & --- \\
\hline \multirow{3}{*}{$\begin{array}{l}\text { Setting time Vicat } \\
\text { (minutes) }\end{array}$} & Initial & $45 \mathrm{~min}$. & 120 & 121 \\
\hline & Final & 600 max. & 307 & 310 \\
\hline & False setting $\%$ & - & 58 & 61 \\
\hline \multirow{5}{*}{$\begin{array}{c}\text { Compressive } \\
\text { strength }\left(\mathrm{N} / \mathrm{mm}^{2}\right)\end{array}$} & 1 day & - & 23.7 & 23.8 \\
\hline & 3 days & - & 31.9 & 32.3 \\
\hline & 28 days & $40 \mathrm{~min}$. & 42.4 & 41.8 \\
\hline & Density $\left(\mathrm{g} / \mathrm{cm}^{3}\right)$ & - & 3.05 & 3.05 \\
\hline & $\begin{array}{c}\text { Volumetric Weight } \\
\left(\mathrm{t} / \mathrm{m}^{3}\right)\end{array}$ & - & 1.22 & 1.22 \\
\hline $\begin{array}{c}\text { Sulfate attack } \\
\text { expansion (1 year) }\end{array}$ & $\begin{array}{c}\text { Reference month } \\
\text { (Correspondingly): } \\
\text {-MARCH-2019 } \\
\text {-APRIL-2019 }\end{array}$ & $0.10 \% \max$. & 0.086 & 0.085 \\
\hline
\end{tabular}

4. Drinking water. The water used to carry out the research tests originates from the municipal drinking water intake and is stored in an open-air cistern exclusively for this purpose.

For the purposes of the methodological development of this research, it is considered to evaluate the addition of a new element to the mixtures of hydraulic mortar of cement called for this study as: "Recovered material" (fresh concrete residue), which is used in this work with the objective of reusing it in the elaboration of a mortar mix of resistance to compression of $70 \mathrm{~kg} / \mathrm{cm}^{2}$.

This recovered material is obtained from the CAGSA Concrete treatment plant, to this residue, its physical characteristics will be determined, as well as the other materials that make up the mortar (Cement, water and mine sand) that are already known by the laboratory according to its database, which is updated constantly as part of the quality control of concrete manufactured in CAGSA concretes and which are governed according to the corresponding regulations NMX on aggregates for mortar and concrete.

Explained the above, the procedure to obtain the characteristics of the new material added to the mixture is described, starting with the following activities:

\subsection{Method}

The purpose of this research is to determine if the fine waste of a treatment plant of a concrete plant can be mixed with mine sand andesite type in order to elaboration of a new hydraulic mortar.

The duration of this investigation was two months, regarding the inclusion criteria, the fine material that passes from the 200 sieve is used, recovered from the treatment plant of the concrete plant as a study variable and any material that does not pass the sieve 200 is excluded. This research according to its object of study is classified as: applied, according to the methodology: exploratory, as for its level of information: quantitative, for its sources of information: experimental, and according to its area of study: scientific. The methodology to follow in the research is as follows: Collection of study samples. The samples of the "recovered material" are taken from the waste treatment plant of cells "one and two" of concrete CAGSA. (See Figure 3) 


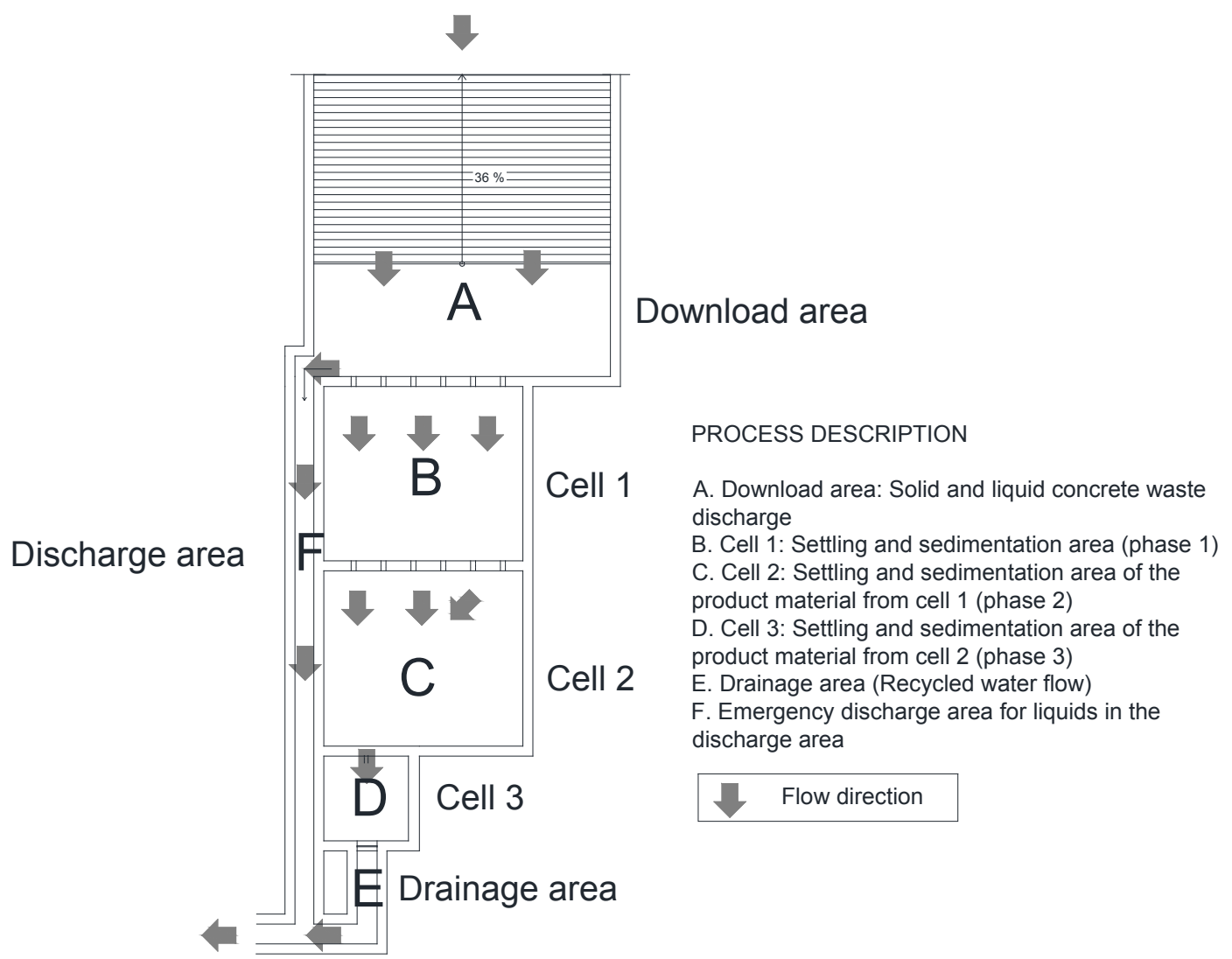

Figure 3. Scheme of a concrete waste treatment plant (CAGSA Concretes)

The recovery of the sample will be carried out in accordance with the NMX (Standards Mexican) [18]. The samples obtained in the field should be reduced to the size required for the tests. The method to determine the condition of saturated and superficially dry is described in NMX $[19,20]$. Once the samples from the study universe have been collected, they will undergo laboratory tests to determine their properties physicals, their SUCS classification, particle size curve, loss due to washing, content of organic matter, colorimetry test, absolute density, loose volumetric weight and weight compact volumetric.

Carrying out the granulometric analysis. - This test allows us to know the classification of fine solid waste according to the Unified Soil Classification System (SUCS) and its granulometric curve, for this purpose, the NMX standard is used [21]. On this point, it is required to know the recovered material, the mass of the material per unit of volume, the volume being the one occupied by the material in a specified container. For this, the NMX standard [22] will be used. Another characteristic to consider in the recovered material is the determination of the finer particle content of the sieve F 0.075 (No. 200) by washing. During this test, the clay particles and others that are dissolved by the washing water, and those that are soluble in water, are separated. This determination will be made using The NMX [23]. In this test, it is required to know the total amount of water contained in the aggregate sample when determining its mass, in order to determine a mix, it can be made up of the sum of the surface water and the absorbed water. The standard under which this test will be carried out is the NMX [24]. This process or test allows us to know if a fine aggregate for concrete and/or mortar, meets the appropriate characteristics for the manufacture thereof, by means of a compression test of test pieces made with a mortar of plastic consistency and with a defined relationship of water-cement. It also records the determination of the effect of organic impurities contained in aggregates according to the NMX [25] on mortar resistance. The determination of these impurities is made according to the NMX [26]. To make this determination, three samples are selected to manufacture the research mortars.

Once the three representative samples have been obtained, they will be mixed together, and a second comparative sample will be made again with the corresponding Standard Mexican. Determination of study sample. - Once the similarity of the physical properties has been verified up to $90 \%$, this mixture will be defined as "Study Sample".

Identification of study groups. - Having defined the study sample, we are already in a position to carry out the corresponding mixtures, so we proceed to prepare a table of nomenclatures that help to identify and control the performance and identification of the specimens under study. (See Table 9) 
Table 9. Identifications of study groups

\begin{tabular}{|c|c|c|c|c|c|}
\hline Group & Subgroup & $\begin{array}{c}\text { Resistance } \\
\left(\mathrm{Kg} / \mathrm{cm}^{2}\right)\end{array}$ & Age (days) & $\begin{array}{c}\text { Identification of the compression } \\
\text { specimen }\end{array}$ & $\begin{array}{c}\begin{array}{c}\text { Specimen } \\
\text { code }\end{array} \\
\end{array}$ \\
\hline \multirow{4}{*}{$\begin{array}{l}\text { TE (benchmark } \\
\text { test) }\end{array}$} & \multirow{4}{*}{ TE-1 } & \multirow{4}{*}{70} & 3 & MM-0.1 & RC-0.1 \\
\hline & & & 7 & MM-0.2 & RC- 0.2 \\
\hline & & & 14 & MM-0.3 & RC-0.3 \\
\hline & & & 28 & MM-0.4 & RC-0.4 \\
\hline \multirow{4}{*}{$\begin{array}{c}\mathrm{A} \\
(10 \%-90 \%)\end{array}$} & \multirow{4}{*}{ A-1 } & \multirow{4}{*}{70} & 3 & MM-1.1 & RC-1.1 \\
\hline & & & 7 & MM-1.2 & $\mathrm{RC}-1.2$ \\
\hline & & & 14 & MM-1.3 & $\mathrm{RC}-1.3$ \\
\hline & & & 28 & MM-1.4 & RC-1.4 \\
\hline \multirow{4}{*}{$\begin{array}{c}\text { B } \\
(20 \%-80 \%)\end{array}$} & \multirow{4}{*}{ B-1 } & \multirow{4}{*}{70} & 3 & MM-2.1 & RC-2.1 \\
\hline & & & 7 & MM-2.2 & $\mathrm{RC}-2.2$ \\
\hline & & & 14 & MM-2.3 & $\mathrm{RC}-2.3$ \\
\hline & & & 28 & MM-2.4 & RC-2.4 \\
\hline \multirow{4}{*}{$\begin{array}{c}\mathrm{C} \\
(30 \%-70 \%)\end{array}$} & \multirow{4}{*}{$\mathrm{C}-1$} & \multirow{4}{*}{70} & 3 & MM-3.1 & $\mathrm{RC}-3.1$ \\
\hline & & & 7 & MM-3.2 & RC-3.2 \\
\hline & & & 14 & MM-3.3 & RC-3.3 \\
\hline & & & 28 & MM-3.4 & RC-3.4 \\
\hline \multirow{4}{*}{$\begin{array}{c}\mathrm{D} \\
(40 \%-60 \%)\end{array}$} & \multirow{4}{*}{ D-1 } & \multirow{4}{*}{70} & 3 & MM-4.1 & RC-4.1 \\
\hline & & & 7 & MM-4.2 & RC-4.2 \\
\hline & & & 14 & MM-4.3 & RC-4.3 \\
\hline & & & 28 & MM-4.4 & RC-4.4 \\
\hline \multirow{4}{*}{$\begin{array}{c}\mathrm{E} \\
(50 \%-50 \%)\end{array}$} & \multirow{4}{*}{ E-1 } & \multirow{4}{*}{70} & 3 & MM-5.1 & RC-5.1 \\
\hline & & & 7 & MM-5.2 & RC-5.2 \\
\hline & & & 14 & MM-5.3 & RC-5.3 \\
\hline & & & 28 & MM-5.4 & RC-5.4 \\
\hline \multirow{4}{*}{$\begin{array}{c}\mathrm{F} \\
(60 \%-40 \%)\end{array}$} & \multirow{4}{*}{ F-1 } & \multirow{4}{*}{70} & 3 & MM-6.1 & RC-6.1 \\
\hline & & & 7 & MM-6.2 & RC-6.2 \\
\hline & & & 14 & MM-6.3 & RC-6.3 \\
\hline & & & 28 & MM-6.4 & RC-6.4 \\
\hline
\end{tabular}

Description of the groups.- After the nomenclatures are drawn up, it is important to make a description of them, so it would be as follows:

Group A (Mix 10-90). - A cement-sand-water mortar mixture is made, with a resistance of $70 \mathrm{~kg} / \mathrm{cm}^{2}$, considering a mixture of sand and cell one residue, using $10 \%$ of recovered material and $90 \%$ of sand, Samples will be taken at 3, 7, 14 and 28 days to determine their resistance to compression at the referred ages. Group B.(Mix 20-90). A cement-sand-water mortar mixture is made, with a resistance of $70 \mathrm{~kg} / \mathrm{cm}^{2}$, considering a mixture of sand and cell one residue, using $20 \%$ of recovered material and $80 \%$ of sand, Samples were taken at 3, 7, 14 and 28 days to determine their resistance to compression at the referred ages. Group C.- (Mix 30-70). A cement-sand-water mortar mix is made, with a resistance of $70 \mathrm{~kg} / \mathrm{cm}^{2}$, considering a mixture of sand and cell one residue, using $30 \%$ of recovered material and $70 \%$ sand, samples were taken at 3, 7,14 and 28 days to determine their resistance to compression at the referred ages. Group D.- (Mix 40-60). A cement-sand-water mortar mixture will be made, with a resistance of $70 \mathrm{~kg} / \mathrm{cm}^{2}$, considering a mixture of sand and cell one residue, using $40 \%$ of recovered material and $60 \%$ of sand, samples were taken at $3,7,14$ and 28 days to determine their resistance to compression at the referred ages. Group E.- (Mix 50-50). A mixture of cement-sand-water mortar is made, with a resistance of $70 \mathrm{~kg} / \mathrm{cm}^{2}$, considering a mixture of sand and cell one residue, using $50 \%$ of recovered material and $50 \%$ of sand, samples were taken at 3, 7, 14 and 28 days to determine their resistance to compression at the referred ages. Group F.- (Mix 60-40). A cement-sand-water mortar mixture is made, with a resistance of $70 \mathrm{~kg} / \mathrm{cm}^{2}$, considering a mixture of sand and cell one residue, using $60 \%$ of recovered material and $40 \%$ of sand, samples were taken at 3, 7, 14 and 28 days to determine their resistance to compression at the referred ages.

Making Mixes. - Once the sample of fine solid waste that will be added to the sand in certain percentages has been determined, the corresponding mixtures will be made. Number of tests. - According to the nomenclature, 6 study groups of mortar mixtures of 3 specimens each with the 
"study material", and a sample of "normal mortar" as control are designed. Percentage of study material to mix.In the preparation of the specimens, only six groups added the "study material according to the following percentages with respect to the sand: (fine residues - Mine sand): $10 \%$ $-90 \%, 20 \%-80 \%, 30 \%-70,40 \%-60 \%, 50 \%-50 \%, 60 \%$ $-40 \%$, according to the proportions described in Table 10 .

\section{Results}

According to the quantitative research carried out and the laboratory results obtained, it is concluded that a mixture of sand of andesitic origin with the material recovered in the dry state (powder), combined with each other, may be feasible to be used as raw material (sand), for the elaboration of a cement-sand mortar for a compressive strength of $70 \mathrm{~kg} / \mathrm{cm}^{2}$, according to the percentages of $90 \%$ sand- $10 \%$ recovered material, $80 \%$ sand- $20 \%$ recovered material and $70 \%$ sand- $30 \%$ recovered material, which are the most favorable results of the laboratory tests carried out, since the proportions $60 \%$ sand- $40 \%$ recovered material, $50 \%$ sand-50\% recovered material, and $40 \%$ sand- $60 \%$ -recovered material, gave results with more disadvantage for the mortar. (See Table 11 and Figure 4).

Table 10. Proportions of mixtures

\begin{tabular}{|l|c|c|c|c|c|c|c|}
\hline Data & TE-1 & A-1 & B-1 & C-1 & D-1 & E-1 & F-1 \\
\hline CPC 40 RS Cement Cruz Azul (Ton) & 0.240 & 0.240 & 0.240 & 0.240 & 0.240 & 0.240 & 0.240 \\
\hline Drinking water $\left(\mathrm{m}^{3}\right)$ & 0.276 & 0.276 & 0.276 & 0.276 & 0.276 & 0.2511 & 0.2511 \\
\hline Mine sand, bank in Mariano Escobedo Ver. $\left(\mathrm{m}^{3}\right)$ & 1.204 & 0.941 & 0.732 & 0.574 & 0.442 & 0.354 & 0.253 \\
\hline Recycled material $\left(\mathrm{m}^{3}\right)$ & 0 & 0.245 & 0.441 & 0.588 & 0.711 & 0.837 & 0.932 \\
\hline
\end{tabular}

\subsection{Statistical Analysis of Results}

Table 11. Compressive resistances depending on the percentage added of recovered material

\begin{tabular}{|c|c|c|c|c|c|c|}
\hline & 3 Days & 7 Days & 14 Days & 28 Days & Average & S Dev \\
\hline $0 \%$ & 53.204 & 71.315 & 80.371 & 93.955 & 74.711 & 35.967 \\
\hline $10 \%$ & 40.978 & 47.317 & 61.127 & 76.523 & 56.486 & 26.238 \\
\hline $20 \%$ & 32.149 & 42.563 & 53.656 & 64.523 & 48.222 & 23.034 \\
\hline $30 \%$ & 27.168 & 40.978 & 47.091 & 57.731 & 43.242 & 20.798 \\
\hline $40 \%$ & 21.055 & 25.13 & 26.715 & 38.035 & 27.733 & 12.185 \\
\hline $50 \%$ & 18.112 & 22.866 & 27.394 & 30.564 & 24.734 & 11.772 \\
\hline $60 \%$ & 17.206 & 19.923 & 20.376 & 26.036 & 20.885 & 9.389 \\
\hline
\end{tabular}

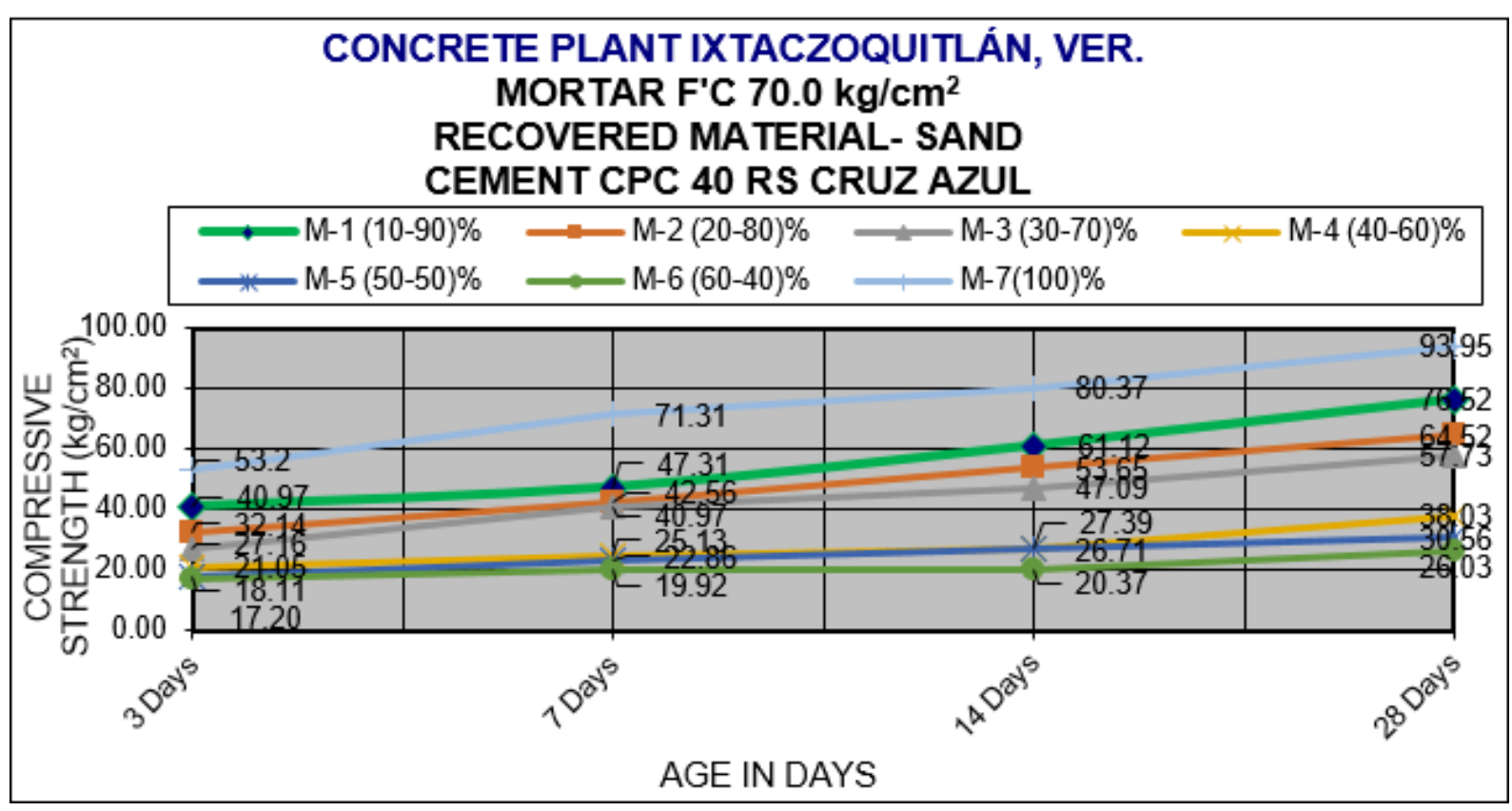

Figure 4. Results of compress resistances according to the addition of recovered aggregate 


\subsection{Student's T Calculation}

According to the results obtained in Table 11, the hypothesis is raised that states that: the increase in the percentage of the material recovered in place of the mine sand affects the resistance to compression. For the verification of such a claim, the data of the row of the witness samples with $0 \%$ to $3,7,14$ and 28 days of retrieved aggregate and the row of the samples with $60 \%$ of aggregate retrieved at 3, 7, 14 and 28 days are used.

$\mathrm{Ho}=$ Null hypothesis $=$ Added $\%$ of waste lowers resistance $\mathrm{H} 1=$ Alternative hypothesis $=$ The added $\%$ of residues do not lower the resistance.

\subsection{Student's T Calculation for Two Samples Assuming Unequal Variances}

F-test for two-sample variances, it is determined with Excel using "PRUEBA. F.N.", $\mathrm{P}$ of $\mathrm{F}=0.031919319$, Verifying that variance are equal or not. Criteria: $\mathrm{P} \leq$ Rejected, $\mathrm{P}>$ Accepted, $\mathrm{P}$-value for $\mathrm{F}=0.031919319$, Significance value 0.05 , Comparative $\mathrm{P}<0.05$, Result $=$ Variances are not equal (rejected). See the calculation results in table 12 .

Table 12. Calculation of $\mathrm{T}$ with the value of $\mathrm{P}$ for $\mathrm{F}$

\begin{tabular}{|c|c|c|}
\hline & $\mathbf{0 \%}$ & $\mathbf{6 0 \%}$ \\
\hline Average & 74.71125 & 20.88525 \\
\hline Variance & 292.1503336 & 13.75078892 \\
\hline Remarks & 4 & 4 \\
\hline $\begin{array}{c}\text { Hypothetical difference of the } \\
\text { means }\end{array}$ & 53.83 & \\
\hline $\begin{array}{c}\text { Degrees of freedom } \\
\text { Statistical T }\end{array}$ & -0.000457403 & \\
\hline P (T $\leq \mathrm{t})$ one tail & 0.49983188 & \\
\hline Critical value of $\mathrm{t}$ (one tail) & 2.353363435 & \\
\hline $\mathrm{P}(\mathrm{T} \leq \mathrm{t})$ two tails & 0.99966376 & \\
\hline Critical value de $\mathrm{t}($ two tails) & 3.182446305 & \\
\hline
\end{tabular}

$\mathrm{P}$ value for $\mathrm{T}=0.49983188, \mathrm{~T}$ value $=-0.000457403$, Group 0\% Degrees of freedom $=n-1=3$, Group 60\% Degrees of freedom $=\mathrm{n}-1=3$, Sum of $\mathrm{n}$ of the 2 groups $=$ $(\mathrm{n} 1-1+\mathrm{n} 2-1)$, Degrees of freedom both groups $=6$, Confidence level 95\%

Significance 5\%

Review using Excel tools: PRUEBA. T.N and DIST. T.INV: $\mathrm{P}$ value for $\mathrm{T}=0.00330319$, Calculating $\mathrm{T}$ with $\mathrm{P}$ using (DIST. T.INV.) with one tail $=0.498735763$ Right side tail
Null hypothesis: There is no statistically significant difference in terms of the average resistance with a confidence level of $95 \%$

Alternative hypothesis: Yes, there is a statistically significant difference in terms of the average resistance with a confidence level of $95 \%$. $\mathrm{P} \leq$ The null hypothesis is rejected, $\mathrm{P}>$ The null hypothesis is accepted. Result

Yes, there is a statistically significant difference in terms of the average resistance with a confidence level of $95 \%$

$0.00330319<0.05$ Null hypothesis rejected.

\subsection{Factor ANOVA Calculation}

ANOVA analysis of 2 factors with one study sample per group to determine if there is a difference between the means being factor 1 the percentage of recovered material added to the samples and factor 2, the resistances at 7, 14 and 28 days. For this analysis, the data in Table 13 are considered.

If $F$ value calculated $>$ Critical value for $F$, YES there is difference, If $\mathrm{F}$ value calculated $<$ Critical value for $\mathrm{F}$ there is NO difference. Conclusion: With respect to the results as a function of the $\%$ added, $\mathrm{F}$ Critical, yes there is a difference between the means compared due to the study factor of the $\%$ added of recovered material used in the study mortars.

Regarding the reuse of fine waste material, would be in a positive way as a mitigation of environmental pollution, since currently this material (study material) is considered as waste and is collected by dump trucks that is thrown away as solid waste on land on the periphery of the town of Ixtaczoquitlán, Veracruz.

In another perspective of conclusion and contribution to the research an improvement proposal is presented to increase the resistance of the recycled mortar by taking advantage of the chemical characteristics of the material recovered for the mortar, whose calcium $(\mathrm{Ca})$ content is abundant, which is achieved by adding chlorine to form chloride of Calcium $(\mathrm{CaCl})$, whose known effect within concrete additives is to improve resistance and the speed of obtaining them (accelerant) with the same amount of cement.

To verify the above, two samples were made, one with a mixture of $50 \%$ recovered material and $50 \%$ andesite mine sand, adding $5 \%$ calcium chloride $(\mathrm{CaCl})$ with respect to the used cement, and another mixture of $20 \%$ recovered material and $80 \%$ andesite mine sand, also adding 5\% calcium chloride to be able to be compared with the results of the same mixtures, but without calcium chloride $(\mathrm{CaCl})$ made in the investigation. The results of the calculations can be seen in Tables 13 and 14. The proportions used for these mixtures were those described in Table 15. 
Table 13. Calculation summary

\begin{tabular}{|c|c|c|c|c|}
\hline Groups & Account & Sum & Average & Variance \\
\hline $0 \%$ & 4 & 298.845 & 74.711 & 292.150 \\
\hline $10 \%$ & 4 & 225.945 & 56.486 & 249.196 \\
\hline $20 \%$ & 4 & 192.891 & 48.222 & 195.205 \\
\hline $30 \%$ & 4 & 172.968 & 43.242 & 162.748 \\
\hline $40 \%$ & 4 & 110.935 & 27.733 & 52.846 \\
\hline $50 \%$ & 4 & 98.936 & 24.734 & 29.468 \\
\hline $60 \%$ & 4 & 83.541 & 20.885 & 13.750 \\
\hline
\end{tabular}

Table 14. Analysis of variance

\begin{tabular}{|c|c|c|c|c|c|c|}
\hline $\begin{array}{c}\text { Origin of } \\
\text { variations }\end{array}$ & Sum of squares & $\begin{array}{c}\text { Degrees of } \\
\text { freedom }\end{array}$ & Average of squares & F & Probability & Critical value for F \\
\hline $\begin{array}{c}\text { Between } \\
\text { groups }\end{array}$ & 9068.142 & 6 & 1511.357 & 10.628 & $1.865 \mathrm{E}-05$ & 2.572 \\
\hline Within groups & 2986.097 & 21 & 142.195 & & & \\
\hline Total & 12054.240 & 27 & & & & \\
\hline
\end{tabular}

Table 15. Proportions of mixtures with calcium chloride (CaCl) for $50 \%-50 \%$ and $20 \%-80 \%$ only

\begin{tabular}{|c|c|c|}
\hline Data & $20 \%-80 \%$ & $50 \%-50 \%$ \\
\hline CPC 40 RS Cement Cruz Azul (Ton) & 0.24 & 0.24 \\
\hline Drinking water $\left(\mathrm{m}^{3}\right)$ & 0.276 & 0.251 \\
\hline Mine sand, bank in Mariano Escobedo Ver. $\left(\mathrm{m}^{3}\right)$ & 0.732 & 0.355 \\
\hline Recycled material $\left(\mathrm{m}^{3}\right)$ & 0.442 & 0.838 \\
\hline Calcium Chloride $(\mathrm{CaCl})$ & 1.2 & 1.2 \\
\hline
\end{tabular}

Once the mixtures were made, the results described in Table 16 and Figure 5 were obtained.

Table 16. Results of Mixes $20 \%-80 \%$ and $50 \%-50$ with $\mathrm{CaCl}$ in $\mathrm{kg} / \mathrm{cm}^{2}$

\begin{tabular}{|c|c|c|}
\hline Description & 3 days & 7 days \\
\hline Mixture (20-80) $+\mathrm{Ca} \mathrm{Cl}$ & 46.41 & 53.88 \\
\hline Mixture (50-50) $+\mathrm{Ca} \mathrm{Cl}$ & 21.51 & 42.563 \\
\hline Mixture (20-80) without Ca Cl & 32.15 & 22.87 \\
\hline Mixture (50-50) without Ca Cl & 18.11 & 71.32 \\
\hline Witness sample & 53.20 & \\
\hline
\end{tabular}

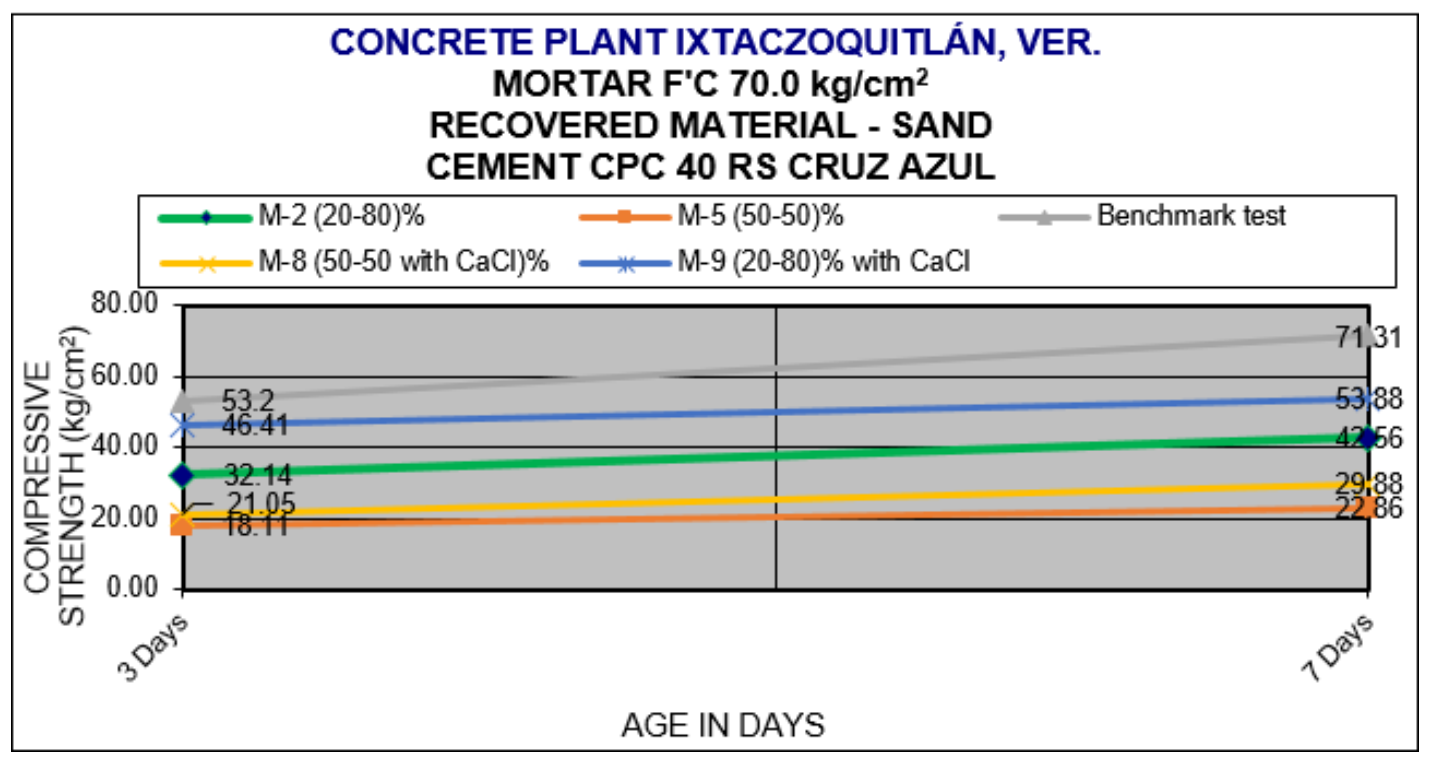

Figure 5. Mixing Resistance Results $20-80 \%$ without $\mathrm{CaCl}, 20-80 \%$ with $\mathrm{CaCl}$ and witness 
Therefore, it is determined that if the resistance of the mixture can be improved combined with the material recovered in dry powder to make recycled mortar with greater resistance to compression, likewise due to its high calcium content, it can be used in an independently, as a raw material to make calcium chloride for applications in the construction industry and specifically for concrete and mortars to obtain better strengths without increasing cement consumption.

It is recommended to follow this line of research because there are studies that can be originated for the use of this recovered material within the construction industry.

\section{Conclusions}

According to the development and experience in the present research, this shows some important elements within it that contribute to the knowledge of the composition, behavior and use of fine waste of a concrete plant for the elaboration of a mortar, which can be concluded as follows:

Based on the fact that the general objective of this research is to investigate whether the fine residue material of a concrete treatment plant combined with mine sand can be used as a raw material for the manufacture of a hydraulic cement mortar with compression resistance of $70 \mathrm{~kg} / \mathrm{cm}^{2}$ looking for the best result that approaches that resistance according to the mixtures of $10 \%-90 \%, 20 \%-80,30 \%-70 \%$, $40 \%-60,50 \%-50 \%$ and $60 \%-40 \%$ of the residue material with respect to mine sand, the results of the research conclude that it can be used only with the best resistance that was obtained and that was with the proportion of $10 \%-90 \%, 10 \%$ of recovered material and $90 \%$ of andesitic sand giving a resistance to 28 days of $76.52 \mathrm{~kg} / \mathrm{cm}^{2}$.

In the corresponding to the resistances obtained of study mixtures, it is important to mention that none of them obtained the same compress strength value compared to the control sample, which does not contain recovered fine aggregate, this because the water/cement ratio is high, since according to the physical results of the recovered material, this has a higher degree of absorption than sand, since it showed a result of percentage of 4.55 water absorption for mine sand which can be seen in Table 2 described in previous paragraphs, and 6.5 absorption percentage for recovered material, which can also be seen in Table 5 previously presented in this research.

Given the analysis of the results of the compressive strength of the mixtures with an addition of the recovered material ranging from $10 \%$ to $60 \%$ of addition of recovered material, it is concluded that this is inversely proportional to the increase in the percentage of aggregate of recovered fine material added to the mixture to elaborate the mortars investigated, this conclusion is supported by the results of compress resistance presented in Figure 4 on previous pages.
In another perspective of this research and having prior knowledge that some setting accelerators are based on calcium chlorides $(\mathrm{CaCl})$, is experimented with the use of this type of additive to observe the effects of the combination of the same with the study mortars for this purpose.

In this regard, it can be concluded that by adding calcium chloride for the production of mortars under study in its different mixtures, helps to have better resistance in them at an early age, this is because the action of the cement is activated faster and reduces the water/cement ratio. With this action, it is possible to have results of compressive strength of mortars, higher than samples without adding the calcium chloride, but even less than the control samples by a shorter margin than those that did not have it.

Based on the comments presented in previous paragraphs, it is proposed as an alternative conclusion of the research, that the use of $\mathrm{CaCl}$ accelerates compressive strength, which was verified with the results of specific samples for this purpose with the following proportions; $20 \%-80 \%$, with and without $\mathrm{CaCl}$ and samples $50 \%-50 \%$, with and without $\mathrm{CaCl}$ having added $5 \%$ of $\mathrm{CaCl}$ to the study samples, it activated a greater resistance at early ages of 3 and 7 days compared to the same proportions without $\mathrm{CaCl}$, coming to affirm that $\mathrm{CaCl}$ is a favorable accelerant to rapid resistance to compression.

Regarding the granulometric classification of the fine recovery material from the treatment plant, this material according to its granulometry is classified according to the Unified Soil Classification System (USCS) as a material ML that includes inorganic silts, rock dust and sandy silts.

Regarding the molecular cohesion and the homogeneity that the recovered material presents once it has been mixed with the mining sand, it is concluded that these are good and are not affected despite increasing the percentage of it in the mixture and reducing the amount of sand, This is based on the study mixtures, since said material despite the fact that in the result of the granulometric analysis carried out, it was observed that it was not retained in any mesh and that it was very loose in the 200 mesh, not retaining the $50 \%$ of the sampled material according to was requested in the classification of the USCS to catalog it within the range of the sands, could be homogenized with mine sand in the proposed percentages for mixtures under study although the density of it varies with respect to mine sand. In general, the reaction of the recovered material was as expected for the elaboration of the mortar not presenting segregation or disintegration thereof in the mix.

In respect of the investigation of the type of chemical elements contained in the recovered fine material, is observed in Table 7 of this document, that the content in a high percentage of the chemical elements in the sample with $91 \%$, is calcium $(\mathrm{Ca})$, from which it is concluded that the main source of its content is directly related to the aggregates and cement that make up the concrete mixtures manufactured in the CAGSA concrete plant (discarding of 
mine sand) and, therefore, of the residues of the same captured in the treatment plant, since the crushed sand is of limestone origin, as well as crushed gravel and cement clinker. Therefore, adding calcium chloride to the study mixtures does not match the resistance obtained from the control samples without and with accelerating additive respectively, but it does help a lot to approaching the values of the same. Regarding calcium content $(\mathrm{Ca})$ in the recovered material and given the percentage of the same in such material (91\%), it can be concluded that this material can be used as raw material for obtaining calcium by means of the relevant chemical processes in a manufacturing plant for accelerating setting additives whose main asset is calcium chloride $(\mathrm{CaCl})$.

For the reproduction of these tests, it must be considered that the recovery of the material to be mixed must be from a treatment plant of concrete waste using the sedimentation and decantation method by means of cells. The waste must be of premixed concrete made with andesite mine sand, crushed limestone sand, crushed gravel 3/4" of limestone origin, as well as cement CPC 40 RS.

With regard to this research compared with other similar ones, as far as the resistances to compression is concerned and always taking as a reference a control sample, it is concluded on the replacement of a percentage of mine sand by recycled fine aggregate, that the higher the percentage added of this material, the resistance to compression decreases, since something constant that this type of aggregates present, is that the absorption of water is increased (modifying its relationship a/c) since its density is lower with respect to the density of mine sand, in one of the case studies, this type of fine aggregate was carbonated and favorable results were obtained, since this process obstructed the porosity of the added material, avoiding the absorption of water and allowing to maintain its water/cement design ratio.

Reiterating that this research only has as main objectives to verify that if the fine residue of the treatment plant of a concrete plant could be used both in a mortar, as well as the use of the same as a raw material for the elaboration of accelerating additives and the obtaining of the resistance to the compression of said mortar to $70 \mathrm{~kg} / \mathrm{cm}^{2}$, it is recommended in future lines of research once the COVID situation is normalized (since this situation restricted access to the electronic microscope equipment of scanning and diffraction of X-rays limiting the research), both of the same researcher and of other researchers interested in the subject, to delve more into the complementary characteristics of the proposed mortar, in terms of the resistance to bending determining its MR (Breaking Module) and as to its durability of said mortar with the tests of porosity, water absorption, as well as the determination of $\mathrm{CSH}$ and $\mathrm{CH}$ gels.

\section{Acknowledgments}

Special thanks to the partners of the company Concrete
CAGSA for the support in human resources, reagents and equipment for carrying out tests. As well as my Advisor and Co-Advisors of the FADU.

\section{REFERENCES}

[1] Elizabeth D. V. N. D., "Strengthening the Culture of Recycling and Reuse from Environmental Axiology", Scientific Magazine, vol. 2, Special Edition Number, pp. 133-153, 2017. DOI: https://doi.org/10.29394/scientific.iss n.2542-2987.2017.0.0.8.133-153 DOI: 10.29394.

[2] Erik. K. L., \& Niels. J. H., "Production of construction waste and recycling", Bulletin $\mathrm{CF}+\mathrm{S}$, no. 2, pp. 9-10, 2016 http://polired.upm.es/index.php/boletincfs/article/view/278 0/2843 ISSN:1578-097X

[3] Elizabeth A. R. U., "Justification", Construction waste Thesis to obtain a bachelor's degree Instituto Politécnico Nacional de México, pp. 4, 2007. URI: https://tesis.ipn.mx/handle/123456789/529

[4] Alfonso A., "Recycling of construction materials", Bulletin $\mathrm{CF}+\mathrm{S}$, no. 2, pp. 6, 2016. http://polired.upm.es/index.php/ boletincfs/article/view/2781/0

[5] María D. B., Samanta E. C. S., Irma M., Claudia C. N., Mónica E. U., Valeria I. F., "Application of the life cycle analysis methodology to evaluate the environmental performance of waste management systems in Latin America", International Magazine of Environmental Pollution, vol. 32, no number, pp. 23-46, 2017. DOI: http://dx.doi.org/10.20937/RICA.2016.32.05.03

[6] Enrique F. L., "Application of residues in the manufacture of industrial mortars", Doctoral dissertation, Universidad de Córdoba UCOPress, pp. XIII, 2016. URI: http://hdl.handle.net/10396/13695

[7] UNE-EN-1015-3-1999, A Spanish Standard-EN-1015-3-"T est methods for mortars for masonry".

[8] Carmelo M. R., "Study of the physical properties and durability of mortars lightened with expanded clay and aggregates with recycled aggregates", Doctoral dissertation, University of Burgos, pp. V, 2015. DOI: http://dx.doi.org/10.36443/10259/4349

[9] Eduardo A. M., Francisco H. O., "Study of fine mortar dust from different sources of waste for the production of recycled concrete", In Proceedings of the 3rd International Congress on Sustainable Construction and Eco-Efficient Solutions, edited by Pilar Mercader Moyano, pp. 941-952, 2017. URI: http://hdl.handle.net/11441/59301

[10] Gilberto A. S. N., Mónica B. L. "Study of the influence of the mortar fine recycled aggregate ratio and the mixing sequence on the behavior of new mortars", Ambiente Construído, 18, pp. 53-69, 2018. DOI: http://dx.doi.org/10.1590/s1678-86212018000200242

[11] Alexis N. R. B., Aldo F. I. V., "Introduction" Study of the mechanical behavior of hydraulic mortar and prototype with addition of wood shavings, Single Edition, Guayaquil: ULVR, 2019. http://repositorio.ulvr.edu.ec/handle/44000/3 427 
[12] Carlos A. M. R., Denniris A. G. P., "Introduction", Compression mechanics in mortars, resistance evaluation in cement mortars with RCD aggregate, Single edition, Catholic University of Colombia, pp. 14-15, 2020. http://creativecommons.org/licences/by-nc/2.5/co/

[13] Álvaro M., N. Torres, Álvaro G., "Evaluation of a mortar prepared with recycled aggregates from carbonation-enhanced concrete", Construction Engineering Magazine, vol. 34, 1, pp. 25-32. 2019. DOI: http://dx.doi.org/10.4067/s0718-50732019000100025 ISSN: 0718-5073

[14] Jongsung S., Cheolwoo P., "Compressive strength and resistance to chloride ion penetration and carbonation of recycled aggregate concrete with varying amount of fly ash and fine recycled aggregate", Waste Management, vol. 31, 11, pp. 2352-2360, 2011. DOI: https://dx.doi.org/10.1016/j .wasman.2011.06.014

[15] Néstor R. B. C., “Conclusions”, Mechanical and durability properties of concrete with recycled aggregate, Single edition, Colombian School of Engineering Julio Garavito, 2013. http://1library.co/document/zkenxj1z-propiedades-m ecanicas-durabilidad-concretos-agregado-reciclado.html

[16] Luis E., Jorge D. B., "Durability performance of concrete made with fine recycled concrete aggregates", Cement and Concrete Composites, vol. 32, 1, pp. 9-14, 2010. DOI: https://dx.doi.org/10.1016/j.cemconcomp.2009.09.005

[17] Julián A. P. M., John J. C.-M., Yessenia C. G. S, Jorge I. L. S, Oswaldo H. F., "Study of the behavior of natural mortar samples subjected to compression stress", Lámpsakos, 20, pp. 22-28, 2018. DOI: http://dx.doi.org/10.21501/2145408 6.2736

[18] NMX-C-170-ONNCCE-2019. Mexican Standard-C-170-Na tional Organization for Standardization and Certification of Construction and Building- "Building Industry-Aggregates -Test Method for Reduction of aggregate samples obtained in the field to the size required for the tests" (Cancels NMX-C-170-1997)".

[19] NMX-C-164-ONNCCE-2002. Mexican Standard -C -164 -
National Organization for Standardization and Certification of Construction and Building- "Building Industry Aggregates -Test Method for Determination of the Specific Mass and Water Absorption of the Coarse Aggregate".

[20] NMX-C-165-ONNCCE-2019. Mexican Standard-C-165National Organization for Standardization and Certification of Construction and Building- "Building Industry Aggregates - Test Method for Determination of relative density and water absorption of fine aggregate" (Cancels NMX-C-165-ONNCCE-2014)".

[21] NMX-C-077-ONNCE-1997. Mexican Standard- C - 077 National Organization for Standardization and Certification of Construction and Building- "Building IndustryAggregates for Concrete-Test Method for Particle size analysis".

[22] NMX-C-073-ONNCCE-2004. Mexican Standard -C - 073 -National Organization for Standardization and Certification of Construction and Building- "Building Industry-Aggregates-Test Method for Volumetric Mass".

[23] NMX-C-084-ONNCCE-2006. Mexican Standard - C - 084 -National Organization for Standardization and Certification of Construction and Building- "Building Industry- Aggregates-Test Method for Particles Finer than the Screen $0.075 \mathrm{~mm}$ (No. 200) by Washing Means".

[24] NMX-C-166-ONNCCE-2006. Mexican Standard - C - 166National Organization for Standardization and Certification of Construction and Building-"Building IndustryAggregates-Test Method for Water content by drying".

[25] NMX-C-088-ONNCCE. Mexican Standard-C-088-National Organization for Standardization and Certification of Construction and Building- "Building Industry Aggregates -Test Method for Determination of organic impurities in fine aggregate".

[26] NMX-C-076-0NNCCE-2002. Mexican Standard - C - 076 - National Organization for Standardization and Certification of Construction and Building- "Building Industry-Aggregates-Test Method for Effects of impurities organic in fine aggregates on the resistance of mortars". 